\title{
Research on Chinese Enterprises' Investment in Kazakhstan Transportation Industry
}

\author{
GAO Yang \\ China (Xinjiang) and Central Asia Regional Economic Cooperation Research Center \\ Xinjiang University of Finance \&Economics \\ Xinjiang Vocational University \\ Urumqi, China
}

\begin{abstract}
This paper mainly introduces the development situation and investment policy of the transportation industry in Kazakhstan, and analyzes the favorable factors and unfavorable factors of the investment environment of Kazakhstan. Based on the particularity of the transportation project, paper proposed when Chinese companies invest in Kazakhstan should fully grasp and use of investment in the country's preferential policy and launch in advance full investigation of the proposed investment project. Furthermore, it is necessary to analysis and evaluation the business; avoid and manage the investment risk; try to use BOT and PPP and other more advanced financing way to break through the existing mode of cooperation.
\end{abstract}

Keywords-Chinese, enterprises, Investment, Kazakhstan, transportation industry

\section{INTRODUCTION}

Along with the development of the tide of regional economic integration and economic globalization, many countries in the world are committed to the regional economic cooperation, complementary advantages and enhance their economic development level. In the "The Belt and Road", infrastructure interoperability is one of the best starting point along the country's regional economic cooperation. Transport cooperation as the vanguard will play a crucial role. To seek China and Kazakhstan's own economic progress, China deepen regional transportation cooperation with Kazakhstan and actively participate in Kazakhstan transportation infrastructure construction, which could strengthen the regional economic development and has positive significance to promote economic globalization.

\section{CURRENT SITUATION OF TRANSPORTATION INDUSTRY IN KAZAKHSTAN}

Kazakhstan ranked seventy-seventh in the World Bank's 2016 Global Logistics Performance Index (LPI) survey, which is the best performing countries in Central Asia. By the end of 2015, in terms of railway construction, Kazakhstan railway total mileage is 15 thousand and 100 kilometers. The railway network distribution is more concentrated. Kazakhstan railway is "south-north" to the railway network, but the density is very low which is only 5.53 kilometers per thousand square kilometers. It is hard to meet the growing demand for transport within the customs union and between the EU and China.
In highway construction, Kazakhstan has more convenient highway network, which can basically meet the domestic transportation demand and achieve Unicom and international transport logistics network. The total road mileage is 97 thousand and 400 kilometers.

In the waterway, Kazakhstan as a landlocked country, compared to other modes of transport is not developed. In aviation infrastructure, the position of air transport is very important. Kazakhstan has the 21 major airports, in which there are 12 air transports to provide international service, and the main airport is Almaty International Airport and Astana Airport.

TABLE I. KAZAKHSTAN GLOBAL COMPETITIVENESS INDEXES

\begin{tabular}{|c|c|c|c|}
\hline & ITEMS & Score & Rank \\
\hline & GCI 2015-2016 & 4.5 & 442 \\
\hline & Quality of overall infrastructure & 4.2 & 62 \\
\hline & Quality of road & 3.1 & 107 \\
\hline Infrastructure & Quality of railroad infrastructure & 4.2 & 27 \\
\hline & Quality of port infrastructure & 2.9 & 114 \\
\hline & Quality of air transport infrastructure & 4.0 & 85 \\
\hline
\end{tabular}

TABLE II. KAZAKHSTAN TRANSPORTATION LOGISTICS ENTERPRISE INCOME IN THE FIRST QUARTER OF 2016 UNIT: ONE BILLION TENGE

\begin{tabular}{|c|c|c|c|}
\hline ITEMS TIME & 2016 & 2015 & Annual growth (\%) \\
\hline Pipeline Transport & 315.2 & 138.2 & 128.1 \\
\hline Road Transport & 205.9 & 211.2 & -2.5 \\
\hline Air Transportation & 44.7 & 33.6 & 33.1 \\
\hline Water Transportation & 1.7 & 1.9 & -11 \\
\hline Total & 567.6 & 384.9 & 47.5 \\
\hline
\end{tabular}

From TABLE I we can see that the overall level of the infrastructure of Kazakhstan is 4.5. Road, rail, port and airport infrastructure index are relatively low. It shows that the transport infrastructure is relatively weak in Kazakhstan, and it still need to improve. In addition, from TABLE II we found 
that Kazakhstan's transport performance is in rapid growth. In first quarter of 2016, transportation logistics company revenue grew by nearly $50 \%$ compared with the same period last year. In Kazakhstan, on the one hand, the development of transport infrastructure is lagging behind; on the other hand, the transportation industry is developing fast. The key to alleviate this contradiction is to vigorously promote the transport infrastructure.

\section{INVESTMENT POLICIES FOR THE DEVELOPMENT OF TRANSPORTATION INDUSTRY IN KAZAKHSTAN}

In the new investment law promulgated by Kazakhstan in 2003, the government has set up procedures for the administration of foreign investment and the encouragement measures. In this code, Kazakhstan encourages foreign investors to invest in priority areas, including land transport, water transport and air transport. In August 2015, "People's Republic of China and Republic of Kazakhstan on a comprehensive strategic partnership in the new stage of the joint declaration" proposed that the two sides will be based on the spirit of openness, cooperation and consultation, the principle of mutual benefit, common on the" Silk Road Economic Belt " initiative and" Bright Road "new economic policy for docking cooperation, and agreed to strengthen interoperability between regions in the above initiatives within the framework of infrastructure construction, trade, tourism and investment cooperation.

The two sides made positive comments on the joint development of the transport infrastructure in the capital of Kazakhstan, including the "Astana urban transport system" and other projects, and will continue to improve the legal basis of bilateral trade and investment cooperation. In " Kazakhstan 2050: unity of purpose, unity of interests, unity in the future state of the union" further clarify the state of the union by diversifying the economy and improve the economic competitiveness. Through preferential policies to the investment, Kazakhstan will develop the transportation and communication infrastructure as to guarantee the steady economic growth and balanced development.

\section{ANALYSIS ON INVESTMENT ENVIRONMENT OF TRANSPORTATION INDUSTRY IN KAZAKHSTAN}

\section{A. Favorable Factors}

Kazakhstan has high degree of openness, perfect legal system, high transparency and a large number of domestic transportation infrastructure construction needs. In the Eurasian Economic Union, Kazakhstan's position is very important. Chinese enterprises can take Kazakhstan as a bridgehead to enter the Eurasian Economic Union market. In addition, in November 30, 2015, Kazakhstan officially became WTO's 162nd members. In accordance with the provisions of the World Trade Organization, Kazakhstan will significantly improve the transparency of foreign investment and trade policies. This is also good news for Chinese enterprises.

According to the Kazakhstan 2020 Traffic Development Program, the railway and highway construction requires 5 billion tenge funds. The outline proposed that Kazakhstan will strive to join the international transport system, and strive to double its transit cargo. So the national highway and railway of Kazakhstan needs to carry out for the large-scale modernization construction. It is expected to total length of road maintenance investment reached 70 thousand $\mathrm{km}$, of which the highway length is 4500 kilometers, other traffic also need to repair. These projects require huge financial support.

In addition, in the end of December 2015, Kazakhstan officially launched the privatization plan. The plan is the Kazakhstan's largest privatization since independence, and promotes the upgrading of infrastructure, oil and gas, metals, minerals, railways and other major economic sectors of some large companies in part and full privatization. The plan will complete 60 major state-owned enterprises and hundreds of small state-owned enterprises to the privatization by the end of 2016, of which the most is focus on transport infrastructure. Kazakhstan government abandoned the preferential right to purchase non-strategic assets in this privatization, which is a good opportunity to Chinese enterprises.

\section{B. Unfavorable Factors}

Kazakhstan government controls of foreign enterprises are increasingly strict. In the past one or two years, Kazakhstan repeatedly introduced some direct restrictions on foreign companies, and foreign enterprises in the corporate tax, security management is more and more strict. The Eurasian Economic Union market integration has great uncertainty. Affected by the financial crisis, the economic downturn, the increase in unemployment led to the deterioration of the social security environment. Although Kazakhstan investment legislation is perfect, the power rent-seeking phenomenon repeated. "Transparency International" released that in 2014 Global Corruption Index, Kazakhstan ranked 126th in 174 countries.

It is understood that Kazakhstan has more than once proposed privatization policy in Kazakhstan established there early privatization. But in the rapid development of the national economy, Kazakhstan has taken the measures of the privatization of nationalized enterprises to recover the country. Therefore, Chinese enterprises should pay attention to the trends of the policies of Kazakhstan in investment.

\section{SUGGESTIONS FOR CHINESE ENTERPRISES TO INVEST IN KAZAKHSTAN TRANSPORTATION INDUSTRY}

First of all, Kazakhstan government encourages foreign investors to enter the transportation industry, and there are relevant provisions on investment incentives. So before entering the country to engage in specific investment, Chinese enterprises must fully understand the investment in the field of transportation and the various preferential policies for foreign investment, in order to make good use of the investment and operation in the future.

Secondly, most of the transportation investment projects have a long construction cycle and long payback period. Therefore, before the investment, the enterprise must carry out a full investigation, analysis and evaluation of the proposed investment projects, including the credit investigation and assessment of the project or customer and related parties; 
analysis of business risk; the implementation of the project itself and so on. Chinese enterprises can make full use of the local government, intermediary organizations and embassies of the state of China to engage in the Counselor's office to obtain as much information as possible from the proposed investment projects as well as real and effective information.

Thirdly, it is necessary for Chinese enterprises to fully study and master the laws and regulations of Kazakhstan, and act in accordance with normal procedures; pay close attention to changes in laws and regulations; integrate into the local market as soon as possible. In recent years Kazakhstan investment policy constantly adjust and improve, Chinese enterprises would choose a relatively short period of investment projects as far as possible. Besides, if Chinese enterprises invest a longer time period of projects and it is better to fight for the protection and both governments' support.

Finally, at present in the field of investment and financing of transportation infrastructure in Kazakhstan, such as BOT, PPP and other more advanced ways of investment and financing is less use. It also shows that the ways of introducing foreign capital in Kazakhstan is still in the early stages of development. In the process of cooperation in the future, the two sides can try to make a breakthrough in the project financing mode, select the appropriate use of items such as BOT and PPP to promote the smooth implementation of bilateral cooperation and deepen the project implementation. Chinese enterprises should focus on sustainable development, and constantly open up new investment cooperation mode, and actively support local capital and private enterprises to participate in the national large-scale projects in Kazakhstan, which also can improve the Chinese enterprises' overall vitality and competitiveness and promote the construction of China and Kazakhstan common market.

\section{REFERENCES}

[1] Information on http://www.mofcom.gov.cn/article/i/dxfw/jlyd/201310/20131000342252 .shtml.2013-10-11

[2] Information on http://kz.mofcom.gov.cn/article/ztdy/201504/20150400930497.shtml.20 15-04-01

[3] ZHAO Ai-ling. China's opportunities for privatization in Kazakhstan [J].China's Foreign Trade, No.1,Jan.2016

[4] SUN Zhuang-zhi. Geo-political Game of Trans-border Traffic in Central Asia Countries[J]. Journal of Xinjiang Normal University(Philosophy and Social Sciences).Vol.37,No.2,Mar.2016 